\title{
Determinants of dam reservoir fisheries impacted by climate change as observed by managers from the entities authorized to exploit these fisheries in East-Central Europe
}

\begin{abstract}
Received - 02 December 2019/Accepted - 28 December 2019. Published online: 31 December 2019; Inland Fisheries Institute in Olsztyn, Poland Citation: Trella M., Czerwiński T., Wołos A. 2019 - Determinants of dam reservoir fisheries impacted by climate change as observed by managers from the entities authorized to exploit these fisheries in East-Central Europe - Fish. Aquat. Life 27: 208-223.
\end{abstract}

\section{Marek Trella, Tomasz Czerwiński, Arkadiusz Wołos}

\begin{abstract}
The aim of this paper is to present and discuss the results of a survey of fishers exploiting dam reservoirs to determine the conditions of conducting fisheries associated primarily with climate change. Overall, questionnaires were obtained from 18 enterprises (of which 16 were chapters of the Polish Anglers Association) regarding a total of 30 reservoirs with a combined surface area of 29,666 ha, which is $49 \%$ of the total surface are of this type of basin in Poland, the largest country in East-Central Europe. This sample is highly representative of all the fisheries conducted in this basin category in Poland and in other East-Central European regions. The following questions referring to the impact of climate change were defined and analyzed based on the answers obtained from the questionnaires: survival of hatchlings, fry, and adult fish; the spawning success of selected fish species; selected hydrological and biological reservoir parameters, the possibility of using and the effectiveness of fishing gears; the length of the recreational fishing season; the size of recreational and commercial fisheries catches of different fish species. Information regarding the impact of reservoirs on fish migrations was also obtained.
\end{abstract}

Keywords: dam reservoir, fisheries, climate change

\footnotetext{
Trella M. ["], Czerwiński T., Wołos A.

Inland Fisheries Institute in Olsztyn, Department of Fisheries

Bioeconomics

ul. Oczapowskiego 10 10-719 Olsztyn, Poland

e-mail:m.trella@infish.com.pl
}

\section{Introduction}

Dam reservoirs are artificial basins constructed by damming river waters with retaining walls (Wiśniewolski 2009). The total surface area of the 140 dam reservoirs in Poland, the largest country in East-Central Europe, is about 60,000 ha, and their total capacity is 3,522 million $\mathrm{m}^{3}$ (Małecki and Pokładek 2010). Most of the reservoirs have small surface areas, and only 15 exceed 1,000 ha (Czerwiński 2014a).

The primary functions of dam reservoirs include the following: water retention; flood control; storing potable water, industrial water, and waters required for agricultural, energy, recreation, recreational and commercial fisheries (Jaguś 2018). In Poland, recreational fisheries are practiced in virtually all dam reservoirs, while commercial fisheries are conducted in only a few (Czerwiński 2014a). Despite many similarities, these artificial reservoirs are not comparable with natural lakes and require a more comprehensive management approach (Launois et al. 2011, Blabolil et al. 2016, Jankowski 2017).

The Department of Fisheries Bioeconomics of the Inland Fisheries Institute has been conducting research about recreational and commercial fisheries reservoirs for years (Falkowski and Wiśniewolski

\footnotetext{
(c) Copyright by Stanisław Sakowicz Inland Fisheries Institute in Olsztyn.

(C) 2019 Author(s). This is an open access article licensed under the Creative Commons Attribution-NonCommercial-NoDerivs License (http://creativecommons.org/licenses/by-nc-nd/3.0/).
} 
2003, Falkowski and Erdmański 2005, Falkowski 2007, 2008, Czerwiński 2014a, 2014b, 2018). The foundation for these studies is the annual analysis of information obtained from a representative sample of entities authorized to fish dam reservoirs in Poland regarding the size of recreational and commercial fisheries catches; the size, structure, and value of stocking; and the conditions for conducting fisheries while maintaining their sustainable development (Czerwiński 2014a). However, global climate change in recent years has forced scientists within the broad field of water management (Arlinghaus et al. 2015, Cooke et al. 2015, Hunt et al. 2016, Kaczkowski et al. 2019) to include a new aspect in research on fisheries management, including that in dam reservoirs, which is specifically the impact of these changes on fisheries.

The aim of this paper was to present and discuss the results of a survey of managers form the entities exploiting dam reservoirs to determine the conditions of conducting fisheries associated primarily with climate change.

\section{Materials and methods}

The analysis was based on completed questionnaires collected in 2019 that were sent to recreational and commercial fisheries enterprises operating in dam reservoirs. In total, questionnaires obtained from 18 entities (of which 16 were chapters of the Polish Anglers Association) regarding a total of 30 reservoirs with a combined surface area of 29,666 ha (Table 1), which is $49 \%$ of the total surface are of this type of basin in Poland.

Based on the responses obtained from the questionnaire, the following issues were defined and analyzed regarding the conditions for conducting fisheries in dam reservoirs, especially those that respondents linked with climate change:

- impact of dam reservoirs on fish migrations;

- impact of climate change on the survival of hatchlings, fry, and adult fish;

- impact of climate change on the effects of the spawning of selected fish species;
- impact of climate change on selected reservoir hydrological and biological parameters;

- possibility of deploying fishing gears and their effectiveness;

- impact of climate change on the length of the recreational fishing season;

- size of recreational and commercial fishing catches of different fish species;

- positive phenomena linked with climate change.

In the analyses, most of the results regarding the questions posed are presented as the percentage distributions of the responses. The same percentage distribution is used to describe the responses to yes or no questions.

The Linkert scale was used with questions that allowed respondents to identify impacts on a scale from 0 to 5 (0-no impact, 1-very little impact, 2-little impact, 3-moderate impact, 4-high impact, 5-very high). For the ranking questions, the analysis focused on the points awarded depending on the answers obtained from the questionnaires, which created a percentage distribution of the points awarded according to the selected degree of impact. A summary with statistical data was also created: rank sum (SR), average $(\mathrm{M})$, standard deviation (SD), median (Me), mode (Mo), first quartile $\left(\mathrm{Q}_{1}\right)$, third quartile $\left(\mathrm{Q}_{3}\right)$ and quartile deviation $(\mathrm{Q})$ to provide a description of the responses and points awarded. Additionally, the parameter of the percentage of no responses to the questions posed in the questionnaire (NR [\%]) was added.

In addition to the analysis of responses using the Linkert scale, questions were also included to which respondents could answer yes or no. These were used to determine basic information on the topic of dam reservoirs and the recreational and/or commercial fisheries conducted in them.

\section{Results}

Most of those who have exploited the fisheries in dam reservoirs long-term have noted the impact of 
Table 1

General data regarding the dam reservoirs studied (PAA - Polish Anglers Association)

\begin{tabular}{|c|c|c|}
\hline Dam reservoir & Entity entitled to exploit the fisheries & Area (ha) \\
\hline Włocławek & PAA Mazowiecki & 7,911 \\
\hline Zegrze & PAA Mazowiecki & 3,852 \\
\hline Siemianówka & PAA Białystok & 3,253 \\
\hline Porąbka & PAA Bielsko-Biała & 386 \\
\hline Tresna & PAA Bielsko-Biała & 1,020 \\
\hline Nowomiejski & PAA Ciechanów & 28 \\
\hline Ruda & PAA Ciechanów & 24 \\
\hline Bielkowo & PAA Gdańsk & 54 \\
\hline Zalew Bledzewski & PAA Gorzów & 80 \\
\hline Dziećkowice & PAA Katowice & 712 \\
\hline Kozłowa Góra & PAA Katowice & 527 \\
\hline Przeczyce & PAA Katowice & 431 \\
\hline Rybnik & PAA Katowice & 398 \\
\hline Przykona & PAA Konin & 120 \\
\hline Słupca & PAA Konin & 266 \\
\hline Słup & PAA Legnica & 292 \\
\hline Turawa & PAA Opole & 1,782 \\
\hline Cieszanowice & PAA Piotrków Trybunalski & 217 \\
\hline Drzewica & PAA Piotrków Trybunalski & 100 \\
\hline Miedzna & PAA Piotrków Trybunalski & 180 \\
\hline Sulejów & PAA Piotrków Trybunalski & 196 \\
\hline Joachimów-Ziemiary & PAA Skierniewice & 36 \\
\hline Lisowo & PAA Szczecin & 175 \\
\hline Rejowice & PAA Szczecin & 75 \\
\hline Sicina & PAA Szczecin & 31 \\
\hline Topola/Kozielno & PAA Wałbrzych & 545 \\
\hline Mietków & PAA Wrocław & 807 \\
\hline Nielisz & PAA Zamość & 834 \\
\hline Dobczyce & Regional Water Management Board in Kraków & 970 \\
\hline Goczałkowice & Gliwice Municipal Water and Sewage Enterprise & 2,600 \\
\hline Total area (ha) & & 29,666 \\
\hline Average area (ha) & & 989 \\
\hline
\end{tabular}

climate change in recent years (63.3\%). Recreational fishing and the use of groundbaits (90\%) are permitted in the vast majority (96.7\%) of the reservoirs surveyed, and $16.7 \%$ of the reservoirs supplied nearby towns with potable water. A disadvantageous fact noted was that only $23.3 \%$ of the reservoirs had fish passes for migrating fish (Fig. 1). Therefore, it is not surprising that the question about impediments to fish migrations such a high percentage of respondents indicated that the reservoirs had a significant impact $(56.7 \%)$ on impeding fish migrations (Fig. 2). However, for questions about the reduced survival of hatchlings and fry or the mortality of adult fish associated with climate change, respondents indicated that the impact of climate change was definitely lower. As many as $40.7 \%$ of respondents indicated that climate change had no impact on adult fish mortality, $29.6 \%$ did not observe any impact on 


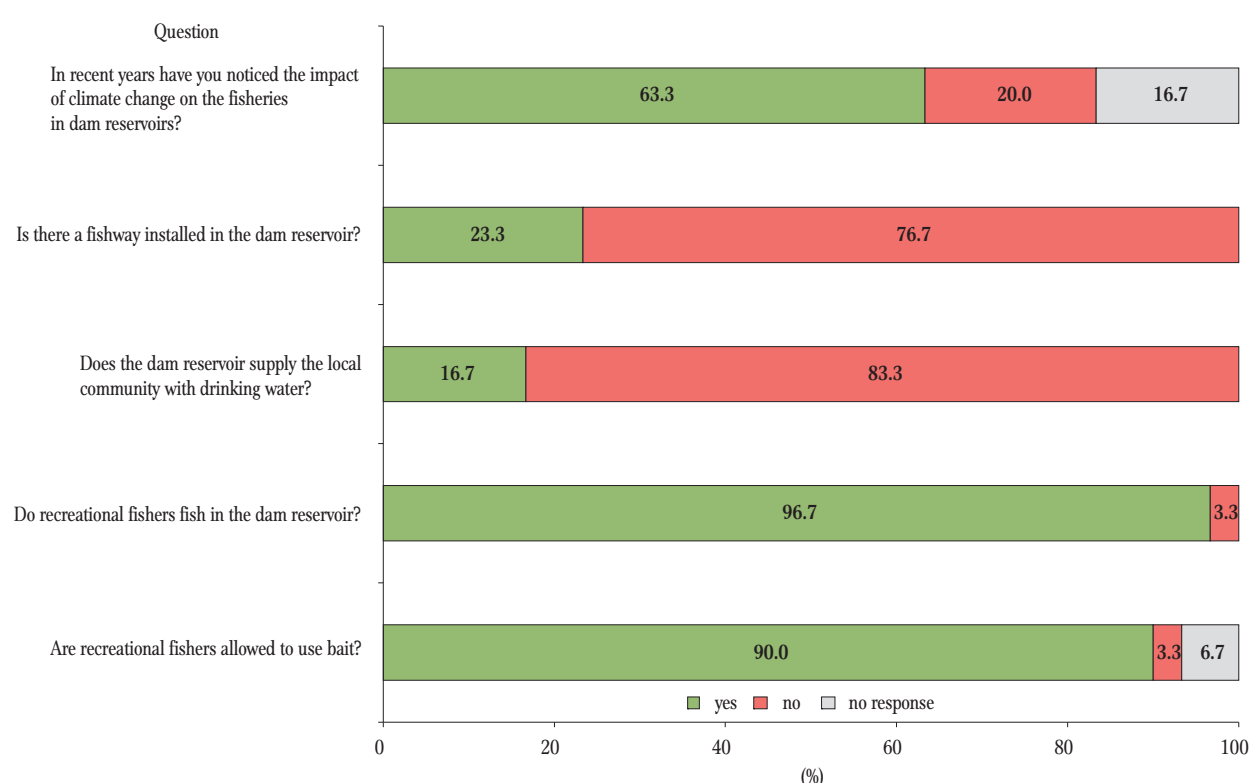

Figure 1. Distribution of responses (\%) to yes/no questions.

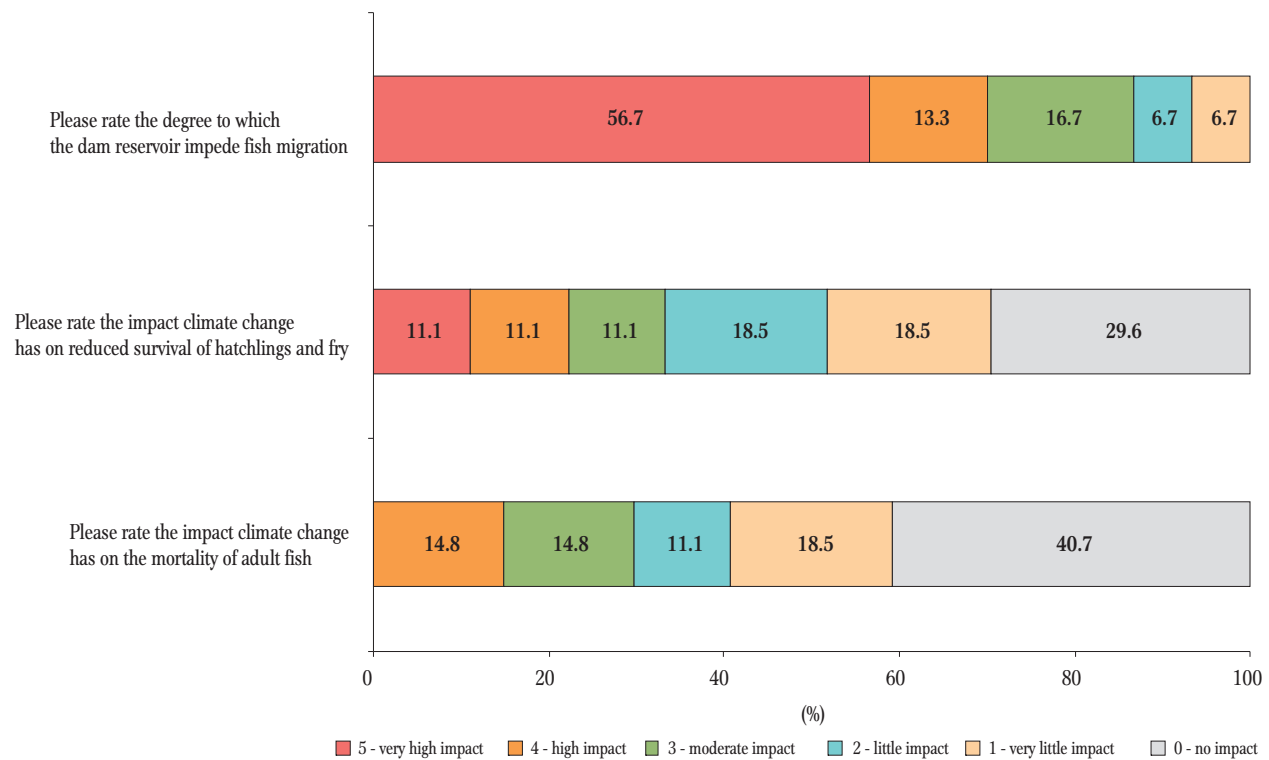

Figure 2. Distribution of responses (\%) to the question about the impact of dam reservoirs and climate change on ichthyofauna.

juvenile stages, and other respondents noted little or very little impact (18.5\%). Only in the case of juvenile fish mortality did $11 \%$ of respondents think that climate change had a significant impact.

According to respondents, pike was the species the spawning of which was most vulnerable to climate change (Fig. 3, Table 2). This species scored the most points (70 SR points) and only $20.7 \%$ of respondents did not note any negative impact. Subsequent species in terms of spawning sensitivity were pikeperch and perch, which had very similar results with 42 and 40 SR points, respectively; however, $34 \%$ of respondents did not note climate change to have had any impact on these species. On the other hand, the species that were least susceptible to climate change were crucian carp and bream, about which most users indicated no $(44.8 \%)$ or very little impact (41.4\%). 


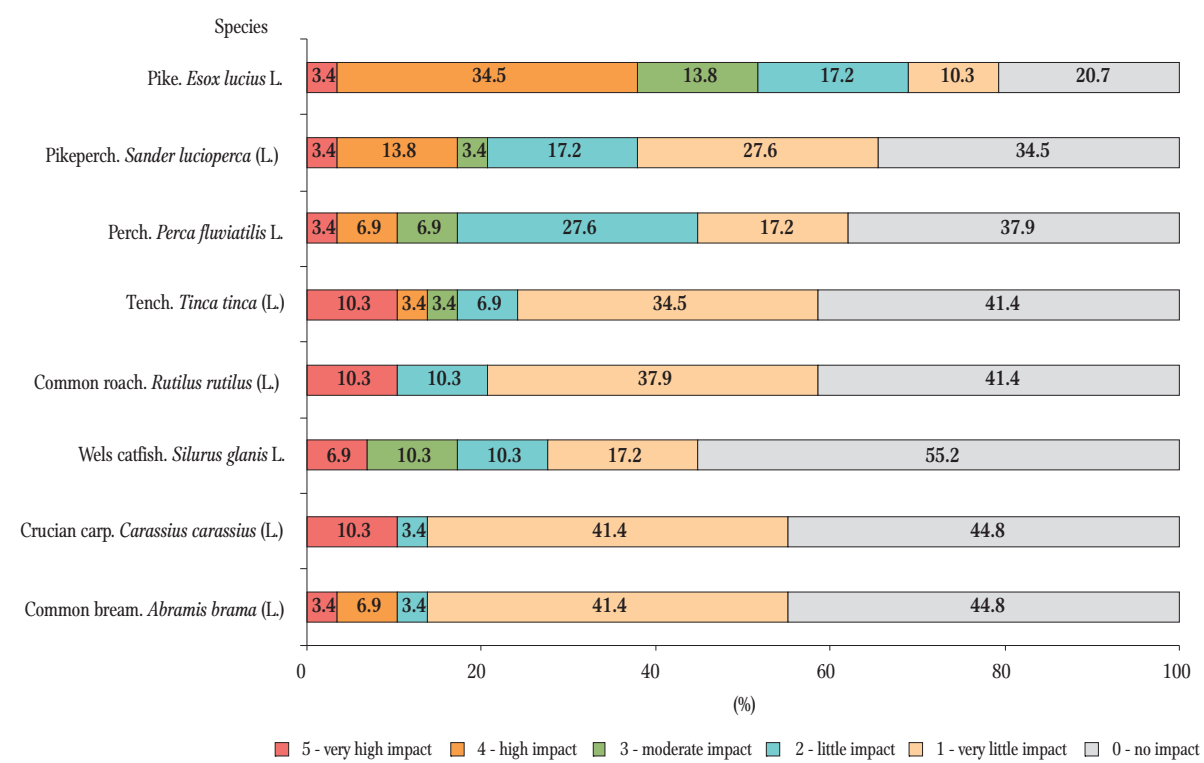

Figure 3. Distribution of responses (\%) to the question about the negative impact of climate change on the effects of the spawning of selected fish species.

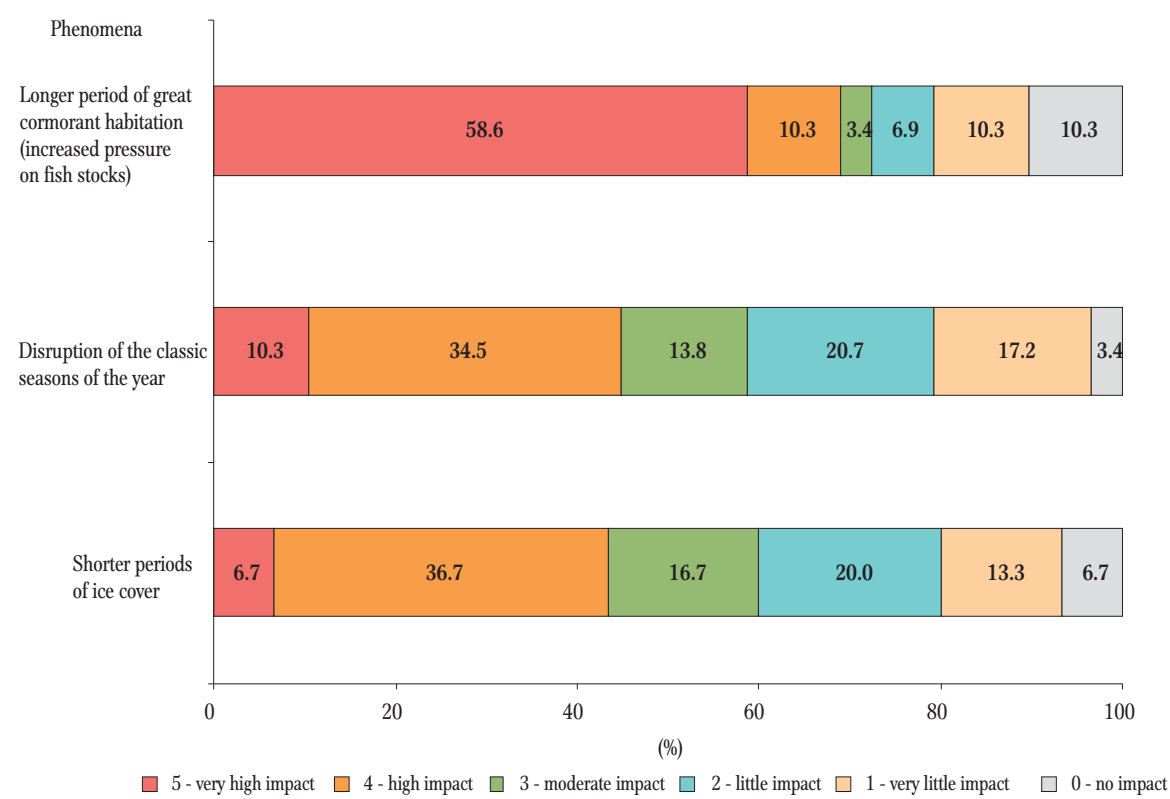

Figure 4. Distribution of responses (\%) regarding the negative impact on fisheries of selected phenomena associated with climate change.

A phenomenon related to climate change that, according to the respondents, had the greatest negative impact on the fisheries, was the longer cormorant residence time (107 points SR), and as many as $58.6 \%$ of respondents believed that this had a very high impact, while only $10.3 \%$ respondents reported that there was no impact (Fig. 4, Table 2). The assessment of typical weather phenomena, such as the disturbance of the classic seasons and the shorter ice cover period, was very similar, with 85 and 84 SR points, respectively, and the percentage distribution of responses was also very similar.

According to those surveyed, increased temperature most negatively affected the fisheries in the summer (as many as $27.6 \%$ of respondents, 90 SR points), but the impact of this was also noted in spring, because $40 \%$ of respondents indicated that its impact was high (84 SR points) (Fig. 5, Table 2). In 


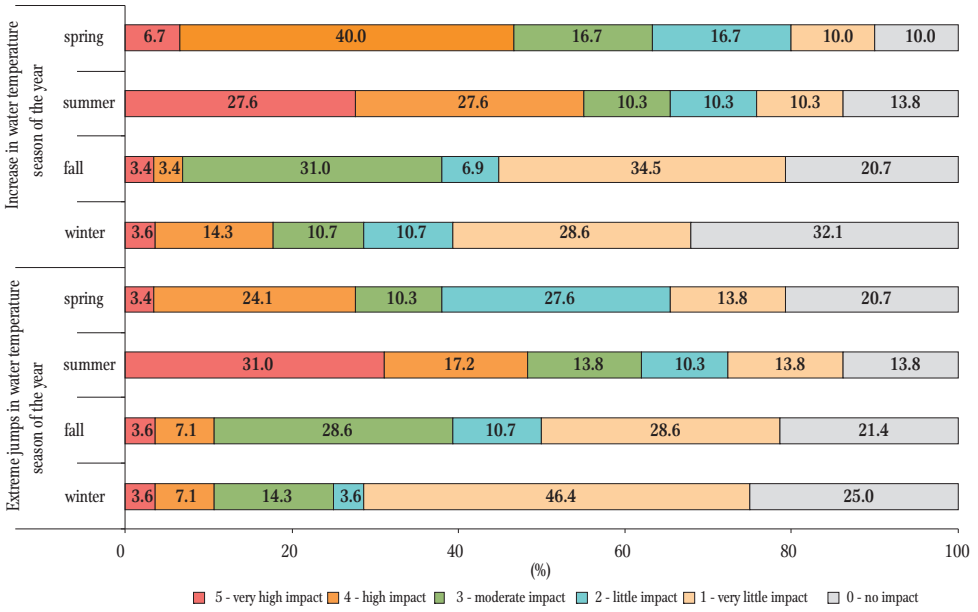

Figure 5. Distribution of responses (\%) regarding selected issues about the negative impact of climate change on water temperature that are affecting fisheries, by seasons of the year.

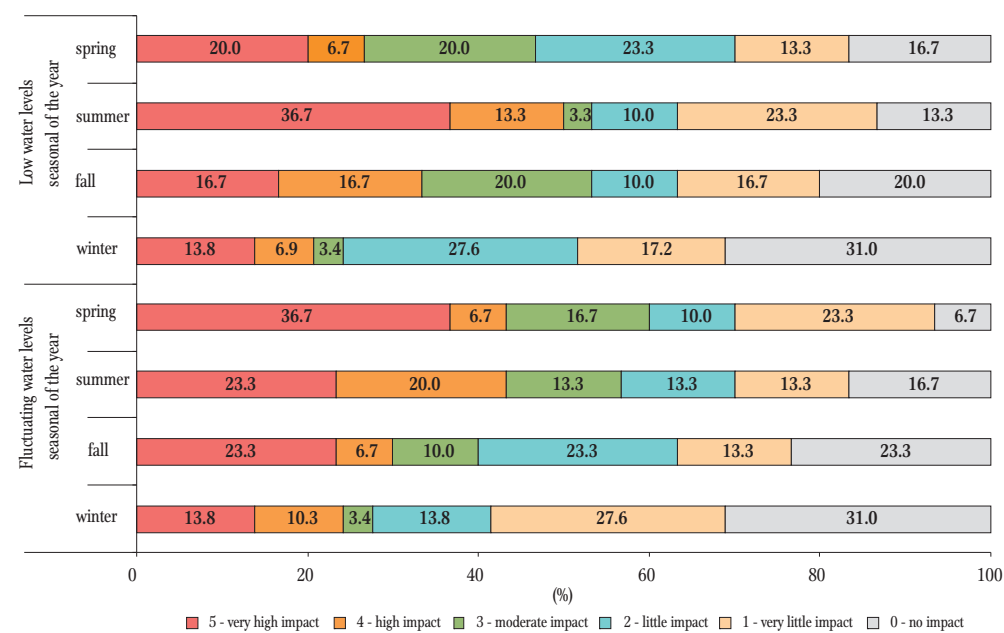

Figure 6. Distribution of responses (\%) regarding selected issues about the negative impact of climate change on water levels that are affecting fisheries, by seasons of the year.

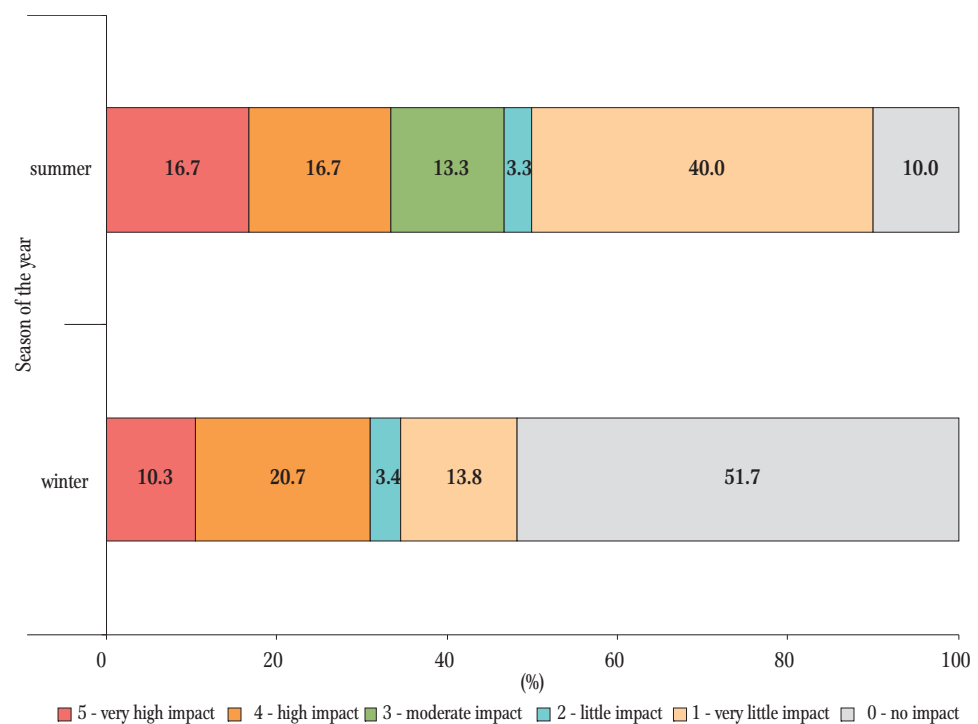

Figure 7. Distribution of responses (\%) regarding oxygen deficits that affect fisheries, by seasons of the year. 


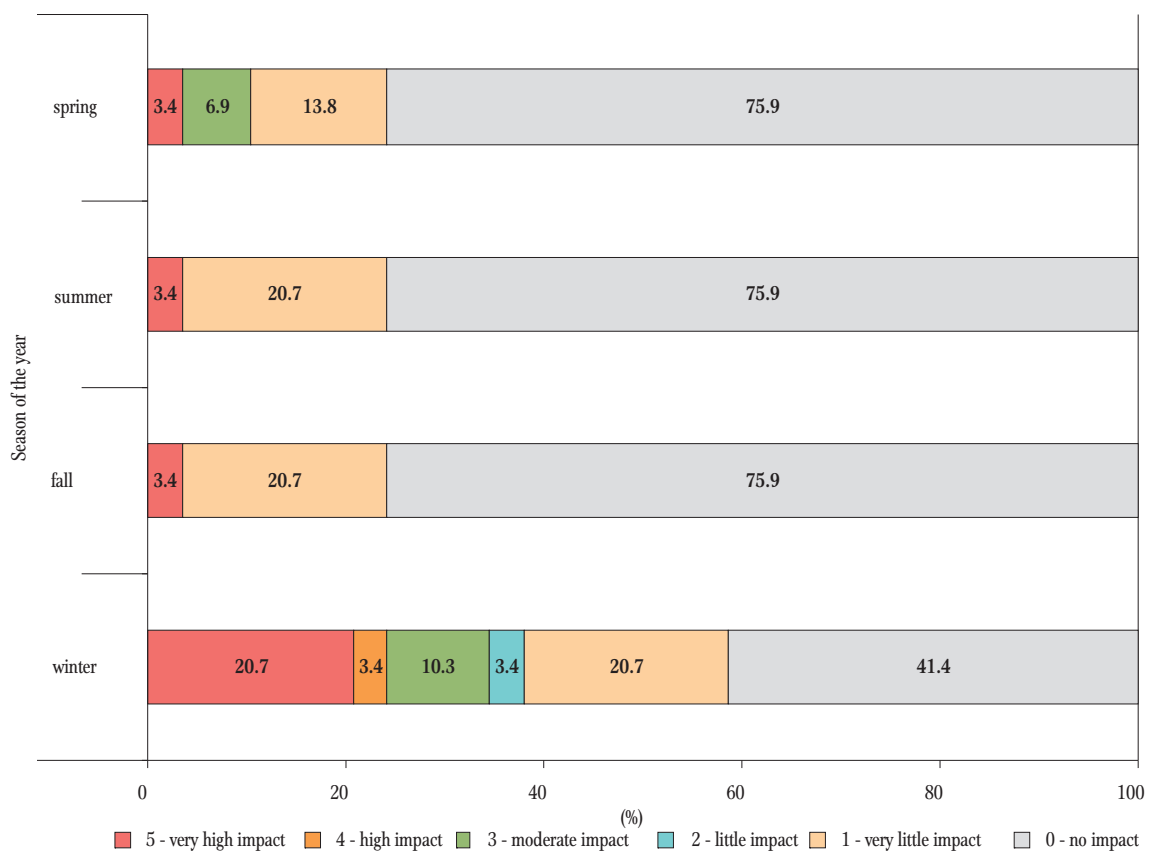

Figure 8. Distribution of responses (\%) regarding the negative impact of climate change on shortening the recreational fishing season, by seasons of the year.

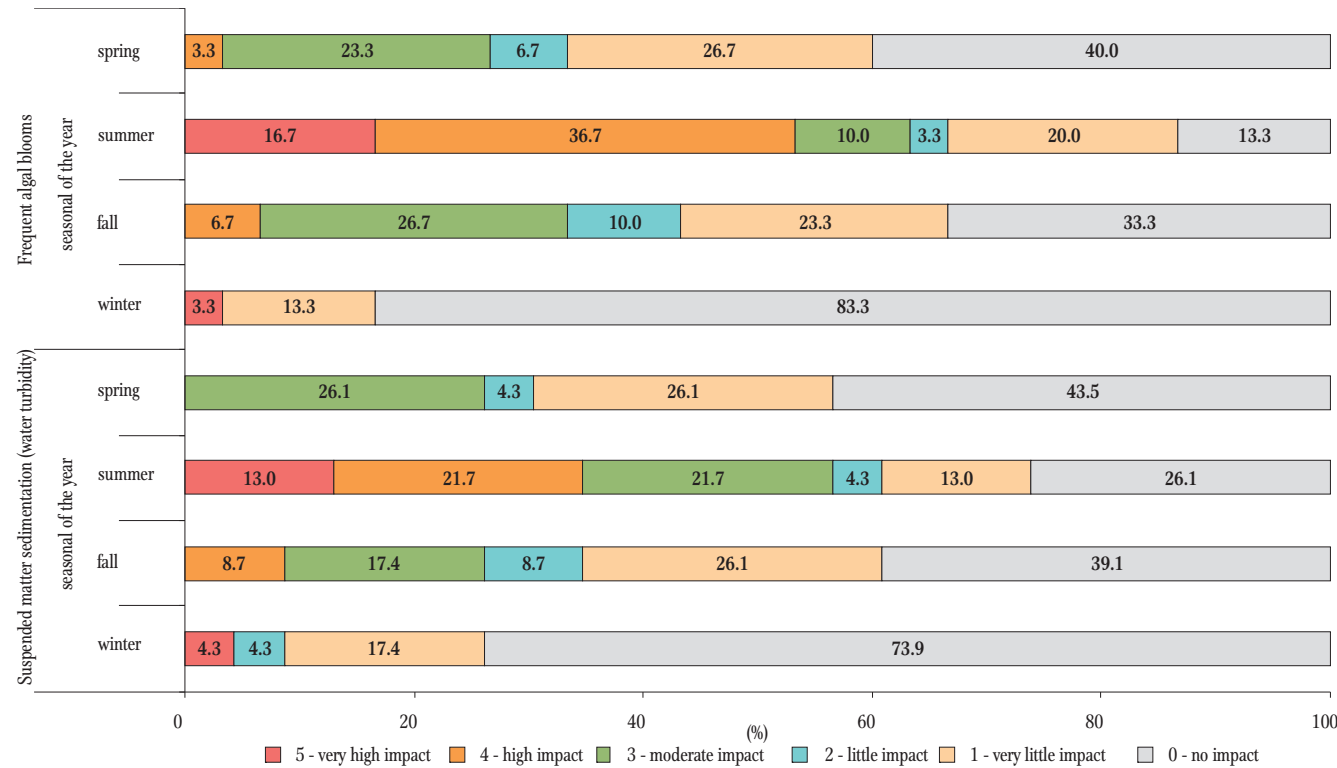

Figure 9. Distribution of responses (\%) regarding selected issues about the negative impact of climate change on water quality, by seasons of the year.

the fall and winter, however, no significant impacts were noted, as was reflected by $20.7 \%$ and $32.1 \%$ of respondents, respectively. Extreme temperature jumps were a distinct problem in the summer with $31 \%$ of respondents (87 SR points) noting that this had a very high impact. In spring, this impact was moderate (62 SR points), while a significant percentage of respondents indicated either the lack of it or its low impact in fall and winter.

Information obtained from the questionnaires showed clearly that low water levels were most disadvantageous in summer with $36.7 \%$ of respondents indicating that this had a very high impact (87 SR points) (Fig. 6, Table 2). Low water levels in spring 


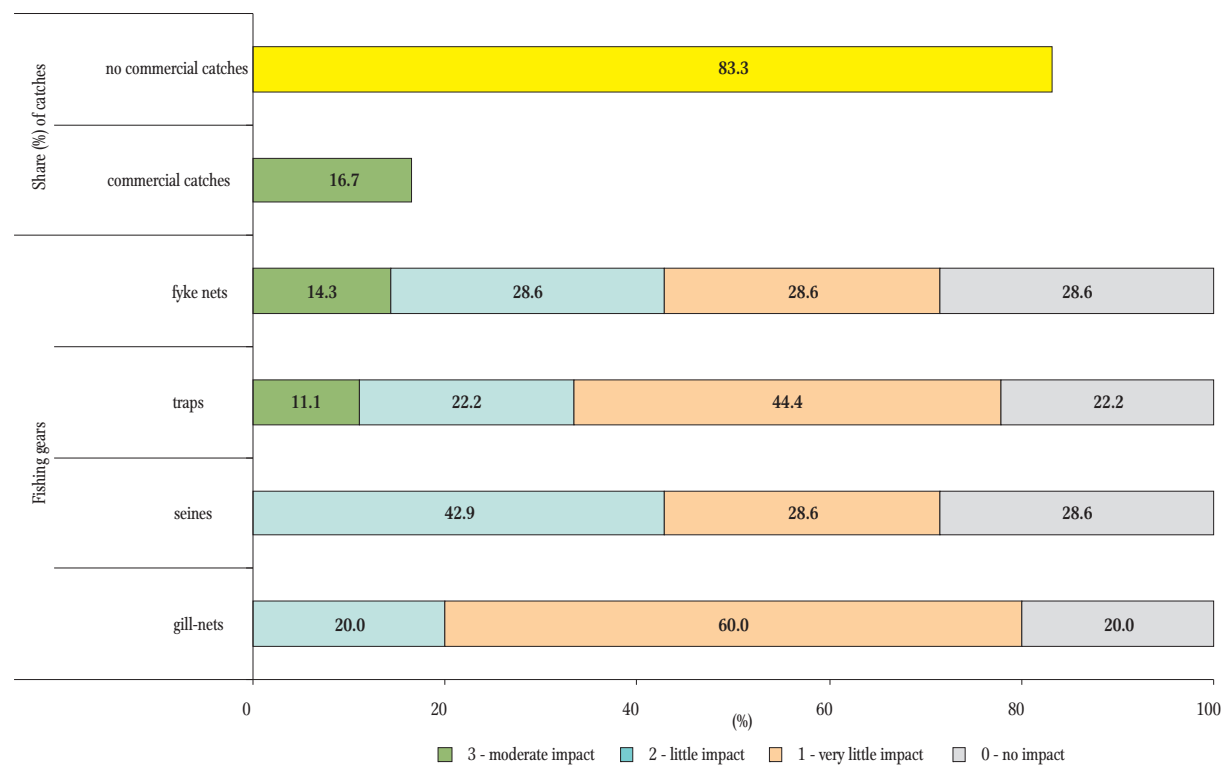

Figure 10. Share (\%) of reservoirs in which commercial fisheries are conducted (or the lack of such fisheries) and the distribution of responses (\%) regarding the negative impact of climate change on the possibility of deploying fishing gears and their effectiveness.

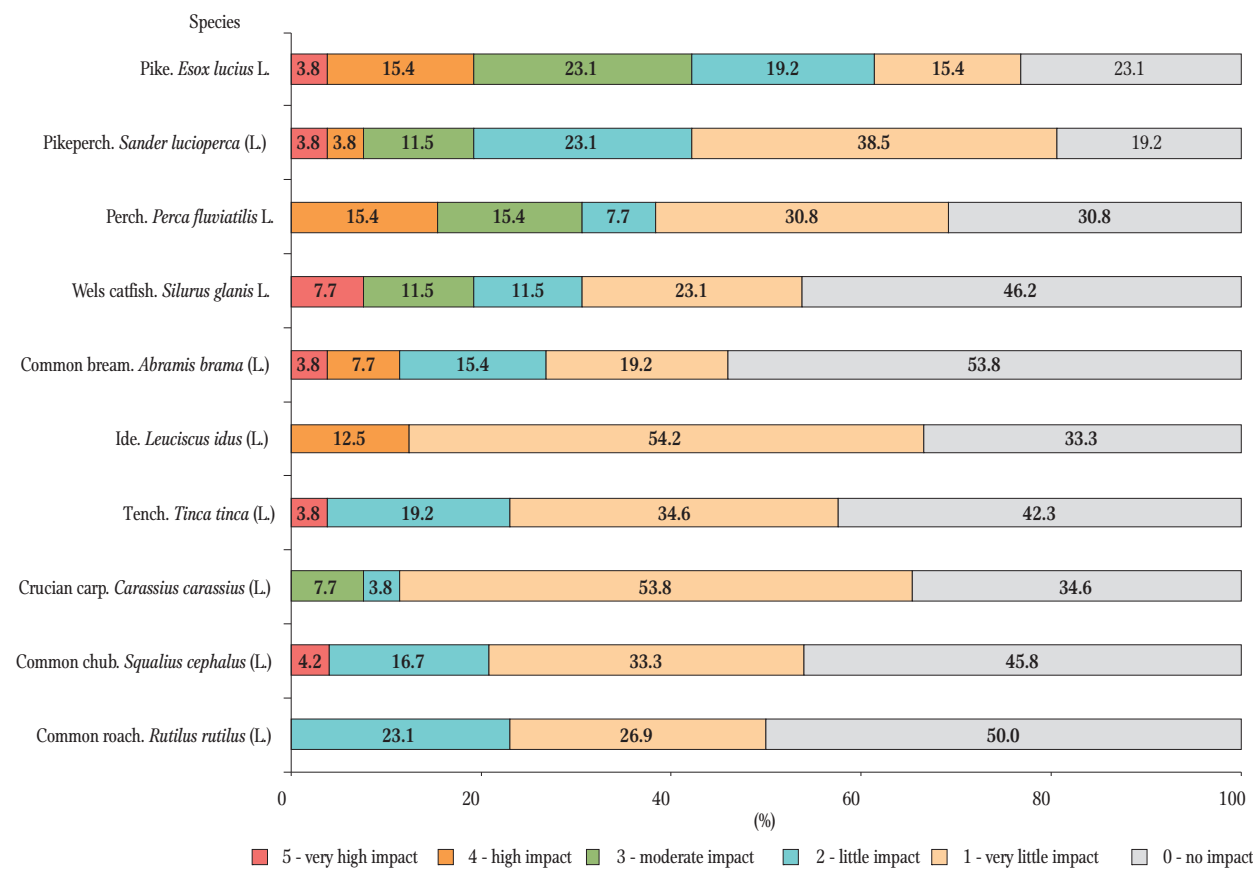

Figure 11. Distribution of responses (\%) regarding the negative impact of climate change on the recreational and commercial catch sizes of particular fish species.

and fall were also a problem to a degree, while only in winter did the impact of this phenomenon on the fisheries decrease. Fluctuations in water levels were the greatest problem in spring according to $36.7 \%$ of respondents who reported this as having a very high impact (91 SR points), while $23.3 \%$ of respondents identified this as having a very high impact in summer and fall (83 and 70 SR points, respectively).

Oxygen deficits, which are linked to the lack of a distinct meteorological winter during the period studied, occurred only in summer and winter; however, as is indicated by the responses obtained, the 


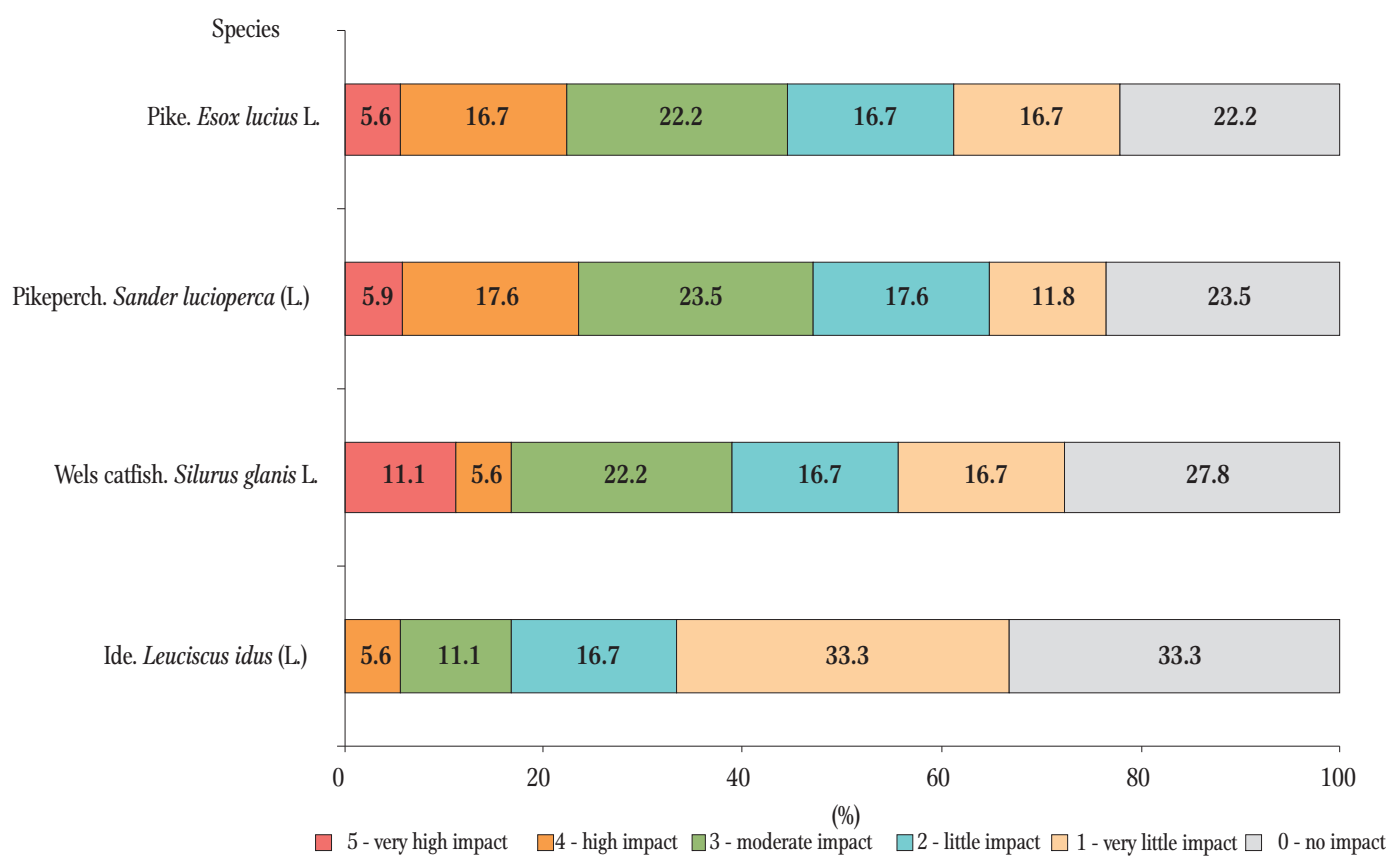

Figure 12. Distribution of responses (\%) regarding the negative impact of climate change on the effective spawning and rearing of fish species under controlled conditions.

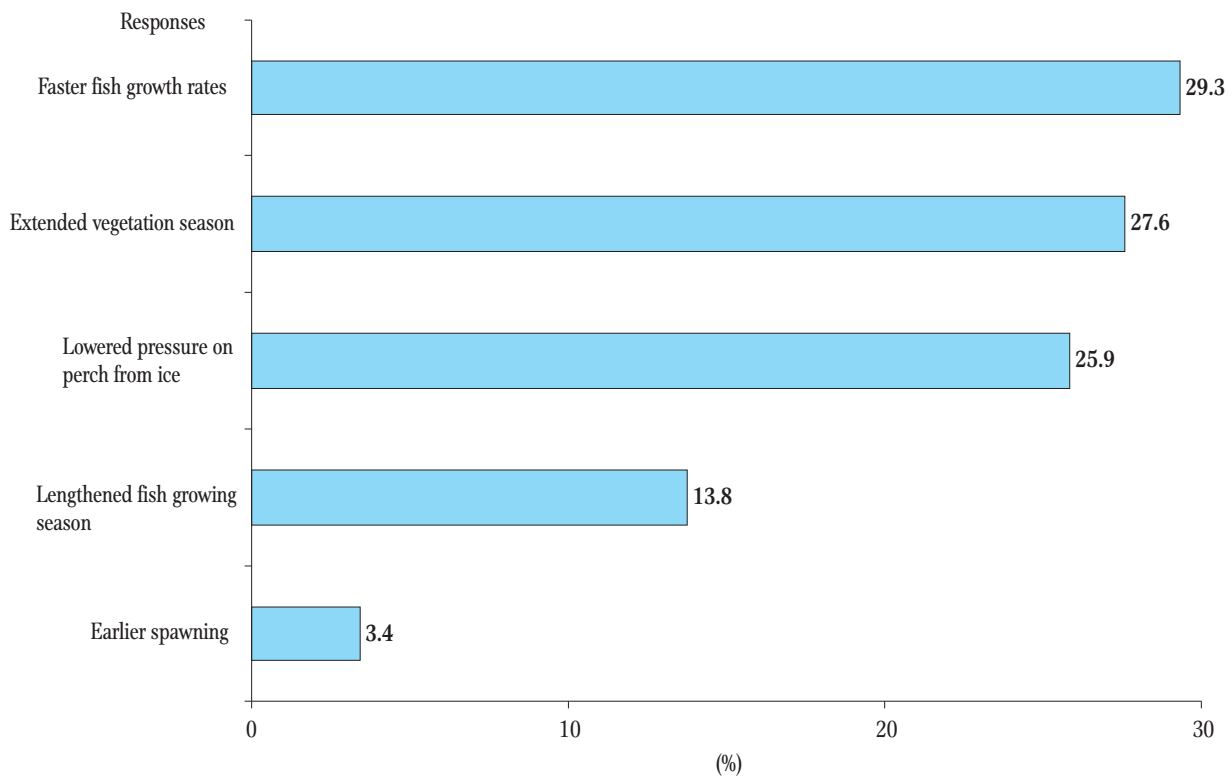

Figure 13. Distribution of responses (\%) to the question about positive phenomena associated with climate change.

impact of this is much higher in summer (71 SR points) and over half of the respondents did not see any negative impact in winter (45 SR points) (Fig. 7, Table 2).

Information about how climate change shortened the recreational fishing season was surprising since this is only a problem in winter and is probably related to the shorter ice cover duration; $20.7 \%$ of respondents indicated that the impact of this was very high (51 SR points), although $41.4 \%$ did not observe any impact even in winter (Fig. 8, Table 2). 
Table 2

Characteristics of responses using the Likert rating scale - comparative comparison (NR [\%] - no response, SR - sum of rank scores, M - mean, SD - standard deviation, Me - median, Mo - mode, $\mathrm{Q}_{1}$ - first quartile, $\mathrm{Q}_{3}$ - third quartile, Q - quartile deviation)

\begin{tabular}{|c|c|c|c|c|c|c|c|c|c|}
\hline & NR [\%] & SR & $\mathrm{M}$ & $\mathrm{SD}$ & $\mathrm{Me}$ & Mo & $\mathrm{Q}_{1}$ & $\mathrm{Q}_{3}$ & Q \\
\hline $\begin{array}{l}\text { Impact of dam reservoirs on impeding fish } \\
\text { migration }\end{array}$ & 0.0 & 122.0 & 4.1 & 1.3 & 5 & 5 & 3 & 5 & 1 \\
\hline $\begin{array}{l}\text { Impact of climate change on lowering hatchling } \\
\text { and fry survival in dam reservoirs }\end{array}$ & 10.0 & 51.0 & 1.9 & 1.7 & 2 & 0 & 0 & 3 & 1.5 \\
\hline $\begin{array}{l}\text { Impact of climate change on adult fish mortality } \\
\text { in dam reservoirs }\end{array}$ & 10.0 & 39.0 & 1.4 & 1.5 & 1 & 0 & 0 & 3 & 1.5 \\
\hline \multicolumn{10}{|c|}{ Impact of climate change on the spawning effects of selected species } \\
\hline pike & 3.3 & 70.0 & 2.4 & 1.6 & 3 & 4 & 1 & 4 & 1.5 \\
\hline pikeperch & 3.3 & 42.0 & 1.4 & 1.5 & 1 & 0 & 0 & 2 & 1 \\
\hline perch & 3.3 & 40.0 & 1.4 & 1.4 & 1 & 0 & 0 & 2 & 1 \\
\hline tench & 3.3 & 36.0 & 1.2 & 1.6 & 1 & 0 & 0 & 1 & 0.5 \\
\hline common roach & 3.3 & 32.0 & 1.1 & 1.5 & 1 & 0 & 0 & 1 & 0.5 \\
\hline wels catfish & 3.3 & 30.0 & 1.0 & 1.5 & 0 & 0 & 0 & 2 & 1 \\
\hline crucian carp & 3.3 & 29.0 & 1.0 & 1.5 & 1 & 0 & 0 & 1 & 0.5 \\
\hline common bream & 3.3 & 27.0 & 0.9 & 1.3 & 1 & 0 & 0 & 1 & 0.5 \\
\hline \multicolumn{10}{|c|}{ Negative impact of the following phenomena on fisheries } \\
\hline $\begin{array}{l}\text { Longer periods of great cormorant habitation } \\
\text { (increased pressure on fish stocks) }\end{array}$ & 3.3 & 107.0 & 3.8 & 1.9 & 5 & 5 & 2.5 & 5 & 1.25 \\
\hline Shorter periods of ice cover & 0.0 & 85.0 & 2.9 & 1.4 & 3 & 4 & 2 & 4 & 1 \\
\hline Disruption of the classic seasons of the year & 3.3 & 84.0 & 2.9 & 1.4 & 3 & 4 & 2 & 4 & 1 \\
\hline \multicolumn{10}{|l|}{ Increased water temperatures } \\
\hline spring & 0 & 86 & 2.9 & 1.5 & 3 & 4 & 2 & 4 & 1 \\
\hline summer & 3.3 & 90 & 3.1 & 1.8 & 4 & 5 & 2 & 5 & 1.5 \\
\hline fall & 3.3 & 50 & 1.7 & 1.4 & 1 & 1 & 1 & 3 & 1 \\
\hline winter & 6.6 & 44 & 1.6 & 1.6 & 1 & 0 & 0 & 3 & 1.5 \\
\hline \multicolumn{10}{|l|}{ Extreme jumps in water temperature } \\
\hline spring & 3.3 & 62.0 & 2.1 & 1.6 & 2 & 2 & 1 & 4 & 1.5 \\
\hline summer & 3.3 & 87.0 & 3.0 & 1.9 & 3 & 5 & 1 & 5 & 2 \\
\hline fall & 6.6 & 51.0 & 1.9 & 1.5 & 1.5 & 1 & 1 & 3 & 1 \\
\hline winter & 6.6 & 40.0 & 1.5 & 1.4 & 1 & 1 & 0.75 & 2.25 & 0.75 \\
\hline \multicolumn{10}{|l|}{ Fluctuating water levels } \\
\hline spring & 0.0 & 91.0 & 3.0 & 1.8 & 3 & 5 & 1 & 5 & 2 \\
\hline summer & 0.0 & 83.0 & 2.8 & 1.8 & 3 & 5 & 1 & 4 & 1.5 \\
\hline fall & 0.0 & 70.0 & 2.3 & 1.9 & 2 & 2 & 1 & 4 & 1.5 \\
\hline winter & 3.3 & 51.0 & 1.8 & 1.8 & 1 & 0 & 0 & 3 & 1.5 \\
\hline \multicolumn{10}{|l|}{ Low water levels } \\
\hline spring & 0.0 & 74.0 & 2.5 & 1.7 & 2 & 2 & 1 & 3.75 & 1.375 \\
\hline summer & 0.0 & 87.0 & 2.9 & 2.0 & 3.5 & 5 & 1 & 5 & 2 \\
\hline fall & 0.0 & 74.0 & 2.5 & 1.8 & 3 & 0 & 1 & 4 & 1.5 \\
\hline winter & 3.3 & 52.0 & 1.8 & 1.7 & 2 & 0 & 0 & 2 & 1 \\
\hline
\end{tabular}


cont. Table 2

\begin{tabular}{|c|c|c|c|c|c|c|c|c|c|}
\hline & NR [\%] & SR & M & $\mathrm{SD}$ & $\mathrm{Me}$ & Mo & $\mathrm{Q}_{1}$ & $\mathrm{Q}_{3}$ & Q \\
\hline \multicolumn{10}{|c|}{ Oxygen deficits } \\
\hline summer & 0.0 & 71.0 & 2.4 & 1.8 & 1.5 & 1 & 1 & 4 & 1.5 \\
\hline winter & 3.3 & 45.0 & 1.6 & 2.0 & 0 & 0 & 0 & 4 & 2 \\
\hline \multicolumn{10}{|c|}{ Shorter recreational fishing season (decreased angling permit sales) } \\
\hline spring & 3.3 & 15.0 & 0.5 & 1.2 & 0 & 0 & 0 & 0 & 0 \\
\hline summer & 3.3 & 11.0 & 0.4 & 1.0 & 0 & 0 & 0 & 0 & 0 \\
\hline fall & 3.3 & 11.0 & 0.4 & 1.0 & 0 & 0 & 0 & 0 & 0 \\
\hline winter & 3.3 & 51.0 & 1.8 & 2.0 & 1 & 0 & 0 & 3 & 1.5 \\
\hline \multicolumn{10}{|c|}{ More frequent algal blooms } \\
\hline spring & 0.0 & 37.0 & 1.2 & 1.3 & 1 & 0 & 0 & 2.75 & 1.375 \\
\hline summer & 0.0 & 86.0 & 2.9 & 1.8 & 4 & 4 & 1 & 4 & 1.5 \\
\hline fall & 0.0 & 45.0 & 1.5 & 1.4 & 1 & 0 & 0 & 3 & 1.5 \\
\hline winter & 0.0 & 9.0 & 0.3 & 1.0 & 0 & 0 & 0 & 0 & 0 \\
\hline \multicolumn{10}{|c|}{ Suspended matter sedimentation (water turbidity) } \\
\hline spring & 23.3 & 26.0 & 1.1 & 1.3 & 1 & 0 & 0 & 2.5 & 1.25 \\
\hline summer & 23.3 & 55.0 & 2.4 & 1.9 & 3 & 0 & 0.5 & 4 & 1.75 \\
\hline fall & 23.3 & 30.0 & 1.3 & 1.4 & 1 & 0 & 0 & 2.5 & 1.25 \\
\hline winter & 23.3 & 11.0 & 0.5 & 1.1 & 0 & 0 & 0 & 0.5 & 0.25 \\
\hline
\end{tabular}

Negative impact on the possibility of deploying fishing gears and their effectiveness (if fishing is conducted)

$\begin{array}{llllllllll}\text { gill-nets } & 0.0 & 10.0 & 1.0 & 0.7 & 1 & 1 & 1 & 1 & 0 \\ \text { seines } & 30.0 & 8.0 & 1.1 & 0.9 & 1 & 2 & 0.5 & 2 & 0.75 \\ \text { traps } & 10.0 & 11.0 & 1.2 & 1.0 & 1 & 1 & 1 & 2 & 0.5 \\ \text { fyke nets } & 30.0 & 9.0 & 1.3 & 1.1 & 1 & 1 & 0.5 & 2 & 0.75\end{array}$

Negative impact on the size of recreational and commercial catches of selected fish species

$\begin{array}{llllllllll}\text { pike } & 13.3 & 53.0 & 2.0 & 1.5 & 2 & 3 & 1 & 3 & 1 \\ \text { pikeperch } & 13.3 & 40.0 & 1.5 & 1.3 & 1 & 1 & 1 & 2 & 0.5 \\ \text { perch } & 13.3 & 40.0 & 1.5 & 1.5 & 1 & 1 & 0 & 3 & 1.5 \\ \text { wels catfish } & 13.3 & 31.0 & 1.2 & 1.5 & 1 & 0 & 0 & 2 & 1 \\ \text { common bream } & 13.3 & 26.0 & 1.0 & 1.4 & 0 & 0 & 0 & 1.75 & 0.875 \\ \text { ide } & 20.0 & 25.0 & 1.0 & 1.2 & 1 & 1 & 0 & 1 & 0.5 \\ \text { tench } & 13.3 & 24.0 & 0.9 & 1.1 & 1 & 0 & 0 & 1 & 0.5 \\ \text { crucian carp } & 13.3 & 22.0 & 0.8 & 0.8 & 1 & 1 & 0 & 1 & 0.5 \\ \text { common chub } & 20.0 & 21.0 & 0.9 & 1.2 & 1 & 0 & 0 & 1 & 0.5 \\ \text { common roach } & 13.3 & 19.0 & 0.7 & 0.8 & 0.5 & 0 & 0 & 1 & 0.5\end{array}$

Negative impact of climate change on the effectiveness of spawning and rearing fish under controlled conditions

\begin{tabular}{llllllllll} 
pike & 40.0 & 38.0 & 2.1 & 1.6 & 2 & 0 & 1 & 3 & 1 \\
pikeperch & 43.3 & 37.0 & 2.2 & 1.6 & 2 & 0 & 1 & 3 & 1 \\
wels catfish & 40.0 & 35.0 & 1.9 & 1.7 & 2 & 0 & 0.25 & 3 & 1.375 \\
ide & 40.0 & 22.0 & 1.2 & 1.2 & 1 & 0 & 0 & 2 & 1 \\
\hline \hline
\end{tabular}


On questions regarding the impact of climate change on water quality, i.e., the occurrence of algal blooms and turbidity, it was not surprising that most respondents chose summer months (86 and 55 SR points, respectively), and more than $80 \%$ did not note such an impact during the winter (Fig. 9, Table 2).

The entities surveyed declared that commercial fishing was only conducted in 5 of 30 reservoirs (16.7\%), but these reservoirs together constituted 63\% of the total surface area covered by the study. Respondents who fished with commercial fishing gear did not specifically note any negative impact of climate change on the possibility of deploying or on the efficiency of these fishing gears. The survey indicated that the use of gill-nets and seines was more resistant to climate change, and problems, although minor, arose when using fyke nets and traps (Fig. 10).

Climate change was noted to have the largest negative impact on the catch sizes of recreational and commercial pike fishing (53 SR points) followed by those of pikeperch and perch (40 SR points each). Apart from wels catfish, the remaining species did not score a combined total of 30 SR points, and many respondents indicated that the impact of climate change was either very small or imperceptible (Fig. 11, Table 2).

Problems stemming from climate change that affected the efficiency of spawning and rearing fish under controlled conditions were noted for the three species of pike, pikeperch, and catfish. These species accumulated similar numbers of SR points and the spread of responses was also similar. A much smaller impact was observed by respondents in the case of ide, with $66 \%$ of respondents indicating that climate change had very little or no impact on this species (Fig. 12, Table 2).

On the open question, which allowed those surveyed to indicate the positive aspects of climate change, most respondents (29.3\%) mentioned faster fish growth, while slightly fewer (27.6\%) indicated that global warming was associated with a prolonged vegetative season. On the other hand, $25.9 \%$ of respondents indicated that the shorter ice cover period would reduce ice fishing, which, in turn, would result in decreased perch fishing pressure during winter. Other positive aspects mentioned included an extended fish growth period (13.8\%) and earlier spawning (3.4\%) (Fig. 13).

\section{Discussion}

According to those who exploit the fisheries of dam reservoirs, climate change does not have the greatest impact on the fish populations inhabiting these basins; the reservoirs themselves have the greatest impact on this since they impede fish migrations. The impact of this has been studied and described repeatedly; dam construction alters natural water flow dynamics (Nilsson and Berggren 2000, Nilsson et. al 2005, Moore et al. 2012), and this, in turn, impacts the migratory routes of many fish species, access to which can either be significantly disrupted or totally inaccessible (Baras et al. 1994, Wiśniewolski 2008, Baras and Lucas 2001, Noonan et al. 2012, Dębowski 2016). This disadvantageous impact is compounded by the modest number of fish passes installed in just $23.3 \%$ of the reservoirs studied. It should also be borne in mind that fish passes do not fully eliminate the problem of impeded fish migration (Roscoe and Hinch 2010, Bunt et al. 2012, Hatry et al. 2013); unfortunately, the effectiveness of many fish passes is low (Noonan et al. 2012).

The second problem that respondents pointed out was the negative impact of the cormorant that is related to climate warming, i.e., its increased pressure on the dam reservoir fish stocks. The cormorant problem in Poland has been the focus of increasingly lively discussion for years, because, according to research, this species is the main consumer of fish in inland waters and coastal lagoons (Krzywosz and Traczuk 2012, Trella 2017), and as such, these birds are a potential threat to many fish populations in Poland and many other countries (Švažas et al. 2011, Winkler et al. 2012, Heikinheimo et al. 2016, Trella and Mickiewicz 2016). The problem of cormorant pressure on fish stocks will increase along with climate change as average temperatures increase and the typical winter shortens, which will result in a notable shortened ice 
cover period, which respondents scored highly. The number of cormorants decreased with increased ice formation on dam reservoirs (Bobrek et al. 2018, Wilk et al. 2019). With increased air temperatures and the resulting, in part, higher trophic status of the reservoirs, water temperatures and fish biomasses will increase, and the periods of cormorant habitation will extend (which it has, in fact, already done) and the numbers of this bird will also increase (White et al. 2015, Klimaszyk and Rzymski 2016).

Respondents also scored problems highly that resulted from perceptible changes in climate. The most significant included increased water temperatures in spring and summer, extreme jumps in water temperatures in summer, water level fluctuations in spring and summer, low water levels from spring to fall, algal blooms (mainly in summer), and oxygen depletion. Reservoirs have a very significant impact on water thermal regimes since they cause disturbances in relationships between river water temperatures and air temperatures (Moniewski and Stolarska 2007). Reservoir thermal stratification throughout the year causes significant temperature changes in both reservoirs and in rivers downstream from them (Wiejaczka 2011). Reservoirs have a significant impact on natural relationships between air and water temperatures; since there is a clear difference between these parameters in comparison to them prior to dam construction, this results in air temperatures having less of an impact on water temperatures in streams in any season of the year (Kedra and Wiejaczka 2017). Because of the potentially adverse impact of thermal sewage, respondents noted a higher intensity of summer algal blooms, which, according to Traczewska (2012), are often more intense in dam reservoirs. It should be remembered, however, that nutrients from anthropogenic sources are the primary cause of algal blooms and increased water trophic status in Polish dam reservoirs (Czaplicka-Kotas et al. 2012). All these factors have a significant impact on fish populations, piscivorous animals (Lessard and Hayes 2003), and water oxygen content. Therefore, the high scores these phenomena received is understandable, because increased water temperatures in reservoirs not only affected fish, they also impacted entire aquatic ecosystems (Olden and Naiman 2010). The changes in reservoir water levels the respondents noted are a very complicated problem because they result from the very function of reservoirs, the priority task of which is water retention for flood control or energy requirements, and not fisheries. Additionally, water level fluctuations also result from the lack of or heavy precipitation, which either exposes or floods large areas of reservoir bottom resulting in the poor littoral zone development or the lack thereof. This zone generally occurs in natural basins (Traczewska 2012), and it is of fundamental importance to the diversity and abundance of fish species (Winfield 2004).

Maintaining sustainable fisheries in dam reservoirs requires sound stocking policy. Phenomena described above, such as temperature jumps or water level fluctuations during spawning periods, significantly impact the development of species and their juvenile stages. According to respondents, climate change has the greatest impact on pike spawning. Currently in Poland, pike is the most important species in stocking policy, and its stocking dominates in all inland waters (lakes, rivers, and dam reservoirs; Mickiewicz and Wołos 2012, Mickiewicz and Trella 2016, 2017, Mickiewicz 2018). During spawning, this species requires favorable hydrological conditions, including increased water levels and longer flooding periods in coastal meadows where spawning occurs (Łozowski et al. 2014). All of this explains why pike received such high scores in the assessment of negative climate change impacts in comparison to other fish species in terms of both spawning (natural and artificial) and in assessing the impact of these changes on recreational fishing.

The remaining parameters tested obtained much lower SR points, which resulted mainly from the fact that the majority of respondents selected the answer "no impact." For some variants of responses, it was not surprising that users did not see any impact on fishing operations; however, on questions pertaining to the use of fishing gear such high percentages of responses indicating the absence of any impact was surprising. According to an FAO report (FAO 2018) on the impact of climate change on fisheries and 
aquaculture, the topic of fishing gear is quite extensively discussed and emphasizes that as climate change progresses the use of current fishing gears will be problematic or even impossible. Equally surprising was the fact that respondents thought that the only impact climate change was having on the length of the recreational fishing season was to shorten it in winter.

\section{Conclusions}

The responses obtained from the questionnaires presented the real problems that those entitled to exploit the fisheries of dam reservoirs are facing, especially the problems the respondents observed to be linked with climate change. Since the answers to the questionnaire were obtained from entities that exploit nearly $50 \%$ of the total area of dam reservoirs, it can be stated that this sample is highly representative of all fisheries conducted in this group of reservoirs in Poland, and one can reasonably assume that this also applies to neighboring regions of Central and Eastern Europe. As is demonstrated in this paper, conducting fisheries in these waters requires a comprehensive approach, and the respondents themselves are mostly aware of current or future climate changes and their impacts on the fisheries. This conclusion of the survey is significant because it is expected that climate change will intensify and significantly affect both recreational and commercial fisheries conducted in dam reservoirs (Kaczkowski et al. 2019). Most of the entities entitled to fish in dam reservoirs do not operate commercial fisheries opting instead for recreational fisheries; however, regardless of the management model chosen, climate change will stimulate increased densities of cyprinids that could require periodic targeted catches of these low value cyprinids.

Author contributions. M.T. wrote the paper, prepared figures, followed up the process of the publication and performed the statistical analysis. M.M. and T.C. designed a survey, collected data, analyzed the data, conducted the review of the literature. M.M., T.C. and A.W. suggested the topic and designed the study. A.W. edited and corrected the paper.

\section{References}

Arlinghaus R., Lorenzen K., Johnson B.M., Cooke S.J., Cowx I.G. 2015 - Management of freshwater fisheries - In: J.F. Craig (Ed.). Freshwater fisheries ecology: 557-579.

Baras E., Lambert H., Philippart J.C. 1994 - A comprehensive assessment of the failure of Barbus barbus spawning migrations through a fish pass in the canalized River Meuse (Belgium) - Aquat. Living Resour. 7: 181-189.

Baras E., Lucas M.C. 2001 - Impact of man's modifications of river hydrology on the migration of freshwater fishes: a mechanistic perspective - Int. J. Ecohydrol. Hydrobiol. 1: 291-304.

Blabolil P., Logez, M., Ricard D., Prchalová, M., Ř́ha M., Sagouis A., Peterka J., Kubečka J., Argillier C. 2016 - An assessment of the ecological potential of Central and Western European reservoirs based on fish communities - Fisheries Research 173(1): 80-87.

Bobrek R., Wilk T., Pępkowska-Król A. 2018 - Occurrence of the great cormorant, Phalacrocorax carbo, in the Polish Carpathian Mountains outside the breeding season Arrival dynamics and abundance at reservoirs - Ornis Pol. 59: 89-106 (in Polish).

Bunt C.M., Castro-Santos T., Haro A. 2012 - Performance of Fish Passage Structure at Upstream Barriers to Migration - River Research and Applications 28: 457-478.

Cooke S.J., Arlinghaus R., Johnson B.M., Cowx I.G 2015 Recreational fisheries in inland waters - In: J.F. Craig (Ed.) - Freshwater fisheries ecology: 449-465.

Czaplicka-Kotas A., Ślusarczyk Z., Pieta M., Szostak A. 2012 - Analysis of dependencies among water quality indicators in Goczałkowicki Reservoir with regard to phytoplankton blooms - Ochrona Środowiska 34(1): 21-27 (in Polish).

Czerwiński T. 2014a - Analysis of fisheries conducted in selected dam reservoirs in 2002-2013 - In: Developing a model for sustainable fisheries and fish resource conservation in dam reservoirs (Eds.) W. Wiśniewolski, P. Buras, Wyd. IRS, Olsztyn: 29-38 (in Polish).

Czerwiński T. 2014b - State of commercial and recreational fisheries in dam reservoirs in 2013 - In: Sustainable exploitation of fisheries resources in light of the state of them in 2013 (Ed.) M. Mickiewicz, Wyd. IRS Olsztyn: 51-60 (in Polish).

Czerwiński T. 2018 - State of commercial and recreational fisheries in dam reservoirs in 2017 - In: Activity of commercial and recreational fisheries enterprises in 2016 (Eds) M. Mickiewicz, A. Wołos. Wyd. IRS, Olsztyn: 45-57 (in Polish). 
Dębowski P. 2016 - Fish passage through the Włocławek Dam fishway in 2015 - Komun. Ryb. 4: 1-7 (in Polish).

Falkowski S., Wiśniewolski W. 2003 - Fisheries in selected Polish dam reservoirs - In: Fisheries 2002. Conference materials IRS i AWRSP, Wyd. IRS, Olsztyn: 71-78 (in Polish).

Falkowski S. 2007 - Fisheries in selected dam reservoirs in 2006 - In: State of fisheries in lakes, rivers, and dam reservoirs (Ed.) M. Mickiewicz, Wyd. IRS, Olsztyn: 85-89 (in Polish).

Falkowski S. 2008 - Fisheries in selected dam reservoirs in 2007 - Training "Improving knowledge and transparency in fisheries conducted in inland waters”, Hotel Park, Olsztyn, 4-5 June 2008 (in Polish).

Falkowski S., Erdmański J. 2005. - Fisheries in the Goczałkowice water supply reservoir from 1965 to 2004 - Scientific and Technical Conference on the Fiftieth Anniversay of the Construction of the Reservoir on the Mała Wisła River in Goczałkowice, Górnośląskie Przedsiębiorstwo Wodociągów w Katowicach: 113-123 (in Polish).

FAO 2018 - Impacts of Climate Change on Fisheries and Aquaculture: Synthesis of Current Knowledge, Adaptation and Mitigation Options - Rome, Italy: FAO Fisheries and Aquaculture. Technical Paper No. 627: 628 p.

Hatry C., Binder T.R., Thiem J.D., Hasler C.T., Smokorowski K.E., Clarke K.D., Katopodis C., Cooke S.J. 2013 - The Status of Fishways in Canada: Trends Identified Using the National CanFishPass Database - Rev. Fish Biol. Fish. 23: 271-281.

Heikinheimo O., Rusanen P., Korhonen K. 2016 - Estimating the mortality caused by great cormorant predation on fish stocks: pikeperch in the Archipelago Sea, northern Baltic Sea, as an example - Can. J. Fish. Aquat. Sci. 73: 84-93.

Hunt L.M., Fenichel E.P., Fulton D.C., Mendelsohn R., Smith J.W., Tunney T.D., Lynch A.J., Paukert C.P., Whitney J.E. 2016 - Identifying Alternate Pathways for Climate Change to Impact Inland Recreational Fishers - Fisheries 41: 362-372.

Jaguś A. 2018 - Economic and social importance of dam reservoirs - a study of the Soła River cascade - Inżynieria Ekologiczna 19(1): 25-35.

Jankowski W. 2017 - Impact on nature of the construction and functioning of dry and multifunctional-experimental reservoirs based on assessments of selected basins Przegląd Przyrodniczy 28(4): 135-151 (in Polish).

Kaczkowski Z., Frankiewicz P., Góralczyk A. 2019 - Relationship between fish assemblage and angler catch in the Sulejów Reservoir, central Poland, in the context of a warming climate - Fish Manage. Ecol. 26: 187-199.

Kedra M., Wiejaczka Ł. 2017 - Climatic and dam-induced impacts on river water temperature: assessment and management implications - Sci. Total Environ. 626: 1474-83.
Klimaszyk P., Rzymski P. 2016 - The complexity of ecological impacts induced by great cormorants - Hydrobiologia 771: 13-31.

Krzywosz T., Traczuk P. 2012 - Cormorants and the lakes of Warmia and Mazury - abundance, diet, and impact on fish stocks and fisheries - In: Cormorants and sustainable exploitation of fisheries resources. Conference materials. Gdynia, 15 November 2012 r., Morski Instytut Rybacki - PIB: 19-28 (in Polish).

Launois L., Veslot J., Irz P., Argillier C. 2011 - Selecting fish-based metrics responding to human pressures in French natural lakes and reservoirs: Towards the development of a fish-based index (FBI) for French lakes Ecol. Freshw. Fish. 20: 120-132.

Lessard J.L., Hayes D.B. 2003 - Effects of elevated water temperature on fish and macroinvertebrate communities below small dams - River Res. Applic. 19: 721-732.

Łozowski B., Małkowski E., Woźnica A., Łaszczyca P., Koprowski R., Wróbel Z., Pasierbiński A., Migula P., Gwiazda R., Pszczeliński Ł., Siudy A. 2014 Ichthyofauna research as a basis for rational fisheries and dam reservoir management based on the example of the Goczałkowice Reservoir - Gospodarka Wodna 8: 308-311 (in Polish).

Małecki Z.J., Pokładek R. 2010 - Significant processes threatening the safety of aquatic basins - Zesz. Nauk. Inż. Ląd. Wod. Kształt. Środ. 2: 33-42 (in Polish).

Mickiewicz M., Wołos A. 2012 - Economic ranking of the importance of fish species to lake fisheries stocking management in Poland - Arch. Pol. Fish. 20: 11-18.

Mickiewicz M. 2018 - Price of fish and stocking material used by entities authorized to exploit fisheries in 2015 and 2017 - Komun. Ryb. 2: 1-6 (in Polish).

Mickiewicz M., Trella M. 2016 - Predatory fish species in lake stocking management - In: Fish hatcheries, rearing, and stocking (Eds) Z. Zakęś, K. Demska-Zakęś, Wyd. IRS, Olsztyn: 265-276 (in Polish).

Mickiewicz M., Trella M. 2017 - Stocking pike (Esox lucius) and its effect in fisheries district waters based on RRW-23 survey questionnaires from 2006 to 2015 - In: Fish hatcheries and diversification of aquaculture production (Eds) Z. Zakęś, K. Demska-Zakęś, Wyd. IRS, Olsztyn: 273-287 (in Polish).

Moniewski P., Stolarska M. 2007 - Effect of natural and anthropogenic factors on basic physicochemical characteristics of water in a small catchment area of the Eódź suburban area - Woda-Środowisko-Obszary Wiejskie 7,1(19): 105-122 (in Polish).

Moore J.N., Arrigoni A.S., Wilcox A.C. 2012 - Impacts of Dams on Flow Regimes in Three Headwater Subbasins of the Columbia River Basin, United States - J. Am. Water Res. Assoc. 54(5): 925-938. 
Nilsson C., Berggren K. 2000 - Alterations of Riparian Ecosystems Caused by River Regulation - BioScience 50: 783-792.

Nilsson C., Reidy C. A., Dynesius M., Revenga C. 2005 - Fragmentation and Flow Regulation of the World's Large River Systems - Science 308: 405-408.

Noonan M.J., Grant, J.W.A. and Jackson, C.D. 2012 A quantitative assessment of fish passage efficiency Fish Fish. 13: 450-464.

Olden J.D., Naiman R.J. 2010 - Incorporating thermal regimes into environmental flows assessments: modifying dam operations to restore freshwater ecosystem integrity - Freshwat. Biol. 55: 86-107.

Roscoe D.W., Hinch S.G. 2010 - Effectiveness Monitoring of Fish Passage Facilities: Historical Trends, Geographic Patterns and Future Directions - Fish Fish. 11: 12-33.

Švažas S., Chukalova N., Grishanov G., Pūtys Ž., Sruoga A., Butkauskas D., Raudonikis L., Prakas P. 2011 - The role of Great cormorant (Phalacrocorax carbo sinensis) for fish stock and dispersal of helminths parasites in the Curonian Lagoon Area - Vet. Med. Zoot. 55:79-85.

Traczewska T.M. 2012 - Ecological problems of retention reservoirs and their multifunctionality, European symposium on Anti-Flood Defences - Today's Problems. Paris Orléans 28-30 March 2012 (in Polish).

Trella M. 2017 - Recreational fisheries in the Vistula Lagoon in 2014 - Detailed analysis and selected factors shaping its development in recent years - Komun. Ryb. 6: 8-14 (in Polish).
Trella M., Mickiewicz M. 2016 - Recreational fisheries pressure in the Polish waters of the Vistula Lagoon and considerations of its potential impact on the development of regional tourism - Arch. Pol. Fish. 24: 231-242.

White C.L., Ip H.S., Meteyer C.U., Walsh D.P., Hall J.S., Carstensen M., Wolf P.C. 2015 - Spatial and temporal patterns of avian paramyxovirus-1 outbreaks in double-crested cormorants (Phalacrocorax auritus) in the USA - J. Wild. Dis. 51(1): 101-112.

Wiejaczka Ł. 2011 - Influence of storage reservoir on the relations between the temperature of water in the river and the air temperature - Scientific Review - Engineering and Environmental Sciences 53: 183-195.

Wilk T., Bobrek R., Pępkowska-Król A. 2019 - The importance of dam reservoirs in the Polish parts of the Carpathian Mountains for wintering and wetland birds Ornis Polonica: 103-123 (in Polish).

Winfield I.J. 2004 - Fish in the littoral zone: ecology, threats and management - Limnologica 34:124-131.

Winkler H.M., Starck C., Myts D. 2012 - Cormorant food and the possible impact on indigenous fish species in the Pomeranian Bay off the coast of Germany - In: The cormorant in sustainable exploitation of fisheries resources, MIR-PIB Gdynia: 4-8 (in Polish).

Wiśniewolski W. 2008 - Hydroelectric facilities and fish Arch. Pol. Fish. 16: 203-212.

Wiśniewolski W. 2009 - Conditions for and management of recreational and commercial fisheries in dam reservoirs Rocz. Nauk. PZW 22: 141-161 (in Polish). 